\title{
Accumulation features of organochlorine pesticides and heavy metals in fish from high mountain lakes and Lhasa River in the Tibetan Plateau
}

\author{
Ruiqiang Yang ${ }^{\mathrm{a}}$, Tandong Yao ${ }^{\mathrm{a}}$, Baiqing Xu ${ }^{\mathrm{a}}$, Guibin Jiang ${ }^{\mathrm{b}, *}$, Xiaodong Xin ${ }^{\mathrm{a}}$ \\ a Institute of Tibetan Plateau Research, Chinese Academy of Sciences, P.O. Box 2871, Beijing 100085, China \\ ${ }^{\mathrm{b}}$ State Key Laboratory of Environmental Chemistry and Ecotoxicology, Research Center for Eco-Environmental Sciences, Chinese Academy of Sciences, \\ P.O. Box 2871, Beijing, 100085, China
}

Received 26 May 2006; accepted 21 August 2006

Available online 2 October 2006

\begin{abstract}
Organochlorine pesticides and heavy metals were analyzed in fish from remote mountain lakes and Lhasa River in Tibetan Plateau. Concentrations of $\sum \mathrm{HCH}, \sum \mathrm{DDT}$ and HCB in fish muscles were in the range of $0.13-2.6 \mathrm{ng} / \mathrm{g}, 0.78-23 \mathrm{ng} / \mathrm{g}, 0.31-3.2 \mathrm{ng} / \mathrm{g}$ based on wet weight, respectively. Heavy metals were routinely found with different levels in fish. The $\mathrm{Cu}$ and $\mathrm{Zn}$ levels were relatively high with the maximum concentrations reaching 2.0 and $6.9 \mu \mathrm{g} / \mathrm{g}$, respectively. Accumulation of OCPs and heavy metals are quite different in tissues and organs. Gill seems to accumulate more OCPs due to absorption by its larger surface per tissue. Heavy metal levels were generally high in liver, eggs and gill, and low in brain and muscle. Results from this study demonstrate that the Tibetan Plateau functions as a regional contaminant convergence zone by long-range atmospheric transport and orographic cold trapping.

(C) 2006 Elsevier Ltd. All rights reserved.
\end{abstract}

Keywords: HCH; DDT; HCB; POPs; Long-range atmospheric transport; Alpine lakes

\section{Introduction}

Evidences that alpine regions function as regional convergence zones for selected persistent organic pollutants (Drooge and Grimalt, 2004; Daly and Wania, 2005; Shen et al., 2005) and heavy metals (Yang et al., 2002) are increasing. Some anthropogenic contaminants are capable of undergoing longrange transport (LRT) in the atmosphere and undergo dry and/or deposition upon encountering relatively cold environments such as those at high elevations (Blais et al., 1998; Davidson et al., 2003) or high latitude (Atlas and Giam, 1981). A precipitate, often in the form of snow, is believed to be an efficient scavenger of atmospheric contaminants (Franz and Eisenreich, 1998; Carrera et al., 2001). Orographic effects often result in a high rate of precipitation in mountain regions.

Consequently, it is of concern whether the Tibetan plateau may be acting as a cold trap for either airborne semi-volatile contaminants or heavy metals because of its dramatic elevated

* Corresponding author. Tel.: +86 1062849334 ; fax: +86 1062849339 .

E-mail address: gbjiang@rcees.ac.cn (G. Jiang). temperature and frequent precipitation. This phenomenon is exacerbated by highly populated and rapidly industrializing countries surrounding this region. In particular, India and China exhibit high levels of pesticide usage and own several polluting industries. It has been estimated that about $5 \times 10^{5}$ tonnes of DDT and more than $10^{6}$ tonnes of technical HCH have been used in India ( $\mathrm{Li}$ and Macdonald, 2005). From the 1950s until its ban in 1983 , China produced and used $2.7 \times 10^{5}$ tonnes of DDT as well as $4.9 \times 10^{6}$ tonnes of technical $\mathrm{HCH}$ ( $\mathrm{Li}$ et al., 1998). Lindane (pure $\gamma-\mathrm{HCH}$ ) and DDT are still being used in lower amounts to control certain insects in tropical and subtropical countries including India and China (UNEP Regional Report, 2002). These contaminants will possibly impact the Tibetan ecosystems for years to come.

Alpine aquatic ecosystems offer "natural experiments" of exposure to atmospheric long-range transported contaminants. Thus, pollutants concentrated in organisms from aquatic environment can be uniquely related to atmospheric deposition in these areas. Fish inhabiting alpine lakes or rivers will be more vulnerable to pollutants because low temperatures and oligotrophic status cause low growth rate, which may result in 


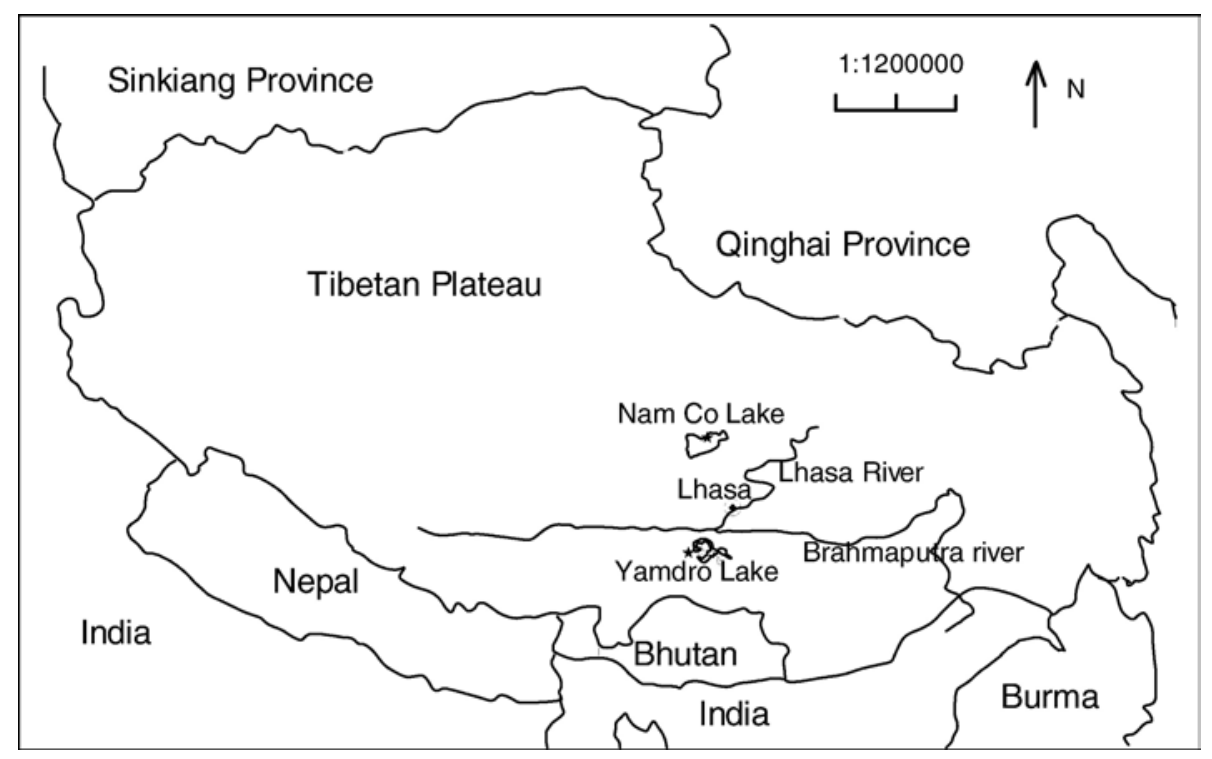

Fig. 1. Map showing the study area and sampling sites.

accumulating higher concentration of pollutants (Kidd et al., 1995). To our knowledge, limited or no information is available concerning bioaccumulation of pollutants by fish inhabiting Tibetan lakes or rivers. In this study, we selected two high mountain lakes and an adjacent river as study areas. Fish samples were collected to explore OCPs and heavy metals in this region, and thus to validate whether the Tibetan Plateau functions as a regional contaminant convergence zone.

\section{Materials and methods}

\subsection{Study area and sample collection}

Two high mountain lakes (Nam Co Lake and Yamdro Lake) and Lhasa River were selected for study (Fig. 1). Nam Co is the largest lake (1920 $\mathrm{km}^{2}$ in area) in Tibet with an altitude of $4718 \mathrm{~m}$ above sea level and is regarded as one of the remotest and least disturbed aquatic environment. Yamdro Lake is situated between Nhagartse and Gongkha with a coverage of $638 \mathrm{~km}^{2}$. The two lakes are among the three famous holy lakes in Tibet. The Lhasa River originates from Nyangqentanglha Mountain on the Tibet Plateau. These areas are largely far from the production and usage of OCPs or industrial input of heavy metals.

Fish samples were collected in August 2005 and they were carefully identified according to the catalog provided by $\mathrm{Wu}$ and $\mathrm{Wu}$ (1992). Fish species belong to the same family (Cyprinidae) and subfamily (Schizothoracinae), which are unique in the Tibetan Plateau. The geographical position and related information of the samples are listed in Table 1. All the samples were immediately transported to the laboratory and frozen at $-20{ }^{\circ} \mathrm{C}$ until use. All the equipments used for sample collection, transportation, and preparation, were free from contamination.

\subsection{Materials}

The OCPs standards of $\alpha-\mathrm{HCH}, \beta-\mathrm{HCH}, \gamma-\mathrm{HCH}, \delta-\mathrm{HCH}, p, p^{\prime}$-DDT, $o, p^{\prime}$ DDT, $p, p^{\prime}$-DDE, $p, p^{\prime}$-DDD and hexachlorobenzene (HCB) were purchased from the National Research Center for Certified Reference Materials of China. The original storage solution was $100 \mathrm{mg} / 1$ in $n$-hexane and further diluted to obtain the desired concentrations. The internal standard $2,2^{\prime} 3,3^{\prime} 4,4^{\prime} 5,5^{\prime} 6$, $6^{\prime}$-decachlorobiphenyl (PCB-209) was purchased from Accustandard, Inc. USA. Florisil (60-100 mesh, Shanghai Chemical Reagent Factory, China) was activated in the oven at $150{ }^{\circ} \mathrm{C}$ for $8 \mathrm{~h}$. The other reagents including $n$-hexane, dichloromethane and anhydrous sodium sulfate, were of analytical-grade (Beijing Chemical Reagent Factory, China). Dichloromethane and $n$-hexane were redistilled before use and a solvent check showed that there was no interference with the target compounds for acceptance. Sodium sulfate was activated in a muffle furnace at $600^{\circ} \mathrm{C}$ for $8 \mathrm{~h}$.

For metal analysis, nitric acid and hydrogen peroxide were guarantee reagents (GR) and purchased from Merck and Beijing Chemical Reagents Company, respectively. Element In (115) in 1\% v/v nitric acid was used as calibration internal standard. All glass vessels were soaked in 1:1 nitric acid for at least $12 \mathrm{~h}$ then rinsed with de-ionized water for several times. The PTFE containers were boiled with

Table 1

Description of geographical location and biological data of the fish samples

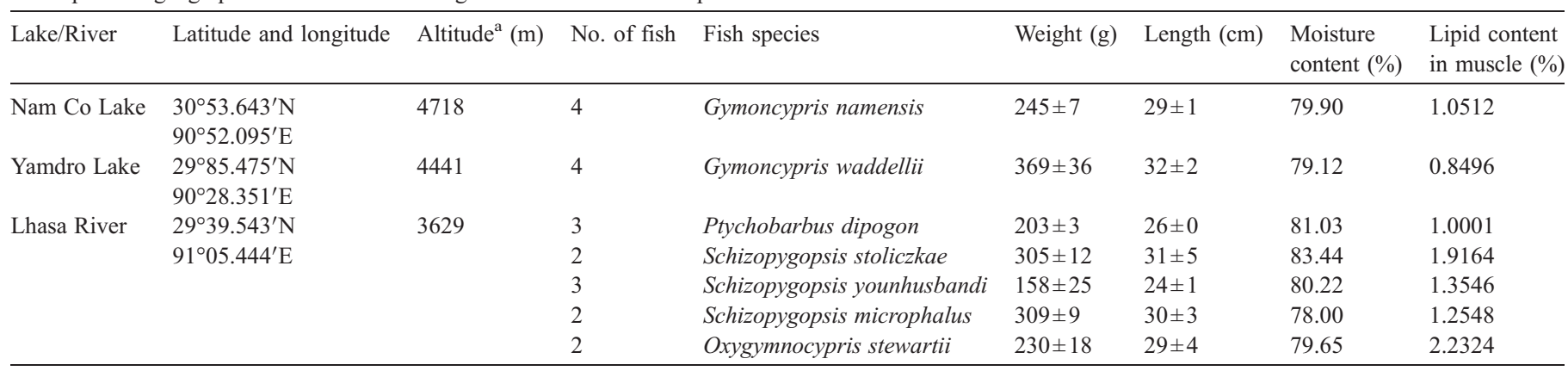

\footnotetext{
${ }^{\text {a }}$ Meters above sea level
} 
Table 2

The recoveries, method detection limits (MDLs), and the relative standard derivation (RSD) of the used analytical procedure

\begin{tabular}{lclc}
\hline Pesticides & Recovery (\%) & MDLs $(\mathrm{ng} / \mathrm{g})$ & RSD $(\%)\left(n^{\mathrm{a}}=5\right)$ \\
\hline$\alpha-\mathrm{HCH}$ & 98 & 0.019 & 7 \\
$\beta-\mathrm{HCH}$ & 90 & 0.046 & 11 \\
$\gamma$-HCH & 95 & 0.022 & 6 \\
$\delta$-HCH & 88 & 0.025 & 13 \\
$\mathrm{HCB}$ & 96 & 0.038 & 4 \\
$p, p^{\prime}$-DDE & 103 & 0.029 & 12 \\
$p, p^{\prime}-\mathrm{DDD}$ & 96 & 0.034 & 12 \\
$o, p^{\prime}$-DDT & 92 & 0.051 & 10 \\
$p, p^{\prime}$-DDT & 90 & 0.055 & 13 \\
\hline
\end{tabular}

${ }^{\text {a }}$ Five times repeated measurements.

Table 3

Determination of heavy metal contents ( $\mu \mathrm{g} / \mathrm{g}$, dry wt) in mussel tissue of certified reference material (GBW 08571)

\begin{tabular}{llllllllll}
\hline & $\mathrm{Mn}$ & $\mathrm{Co}$ & $\mathrm{Ni}$ & $\mathrm{Cu}$ & $\mathrm{Zn}$ & $\mathrm{As}$ & $\mathrm{Se}$ & $\mathrm{Cd}$ & $\mathrm{Pb}$ \\
\hline Certified & $10.2 \pm$ & $0.94 \pm$ & $1.03 \pm$ & $7.7 \pm$ & $138 \pm$ & $6.1 \pm$ & $3.65 \pm$ & $4.5 \pm$ & $1.96 \pm$ \\
& 0.92 & 0.03 & 0.07 & 0.5 & 5.5 & 0.61 & 0.09 & 0.32 & 0.06 \\
Found & $9.0 \pm$ & $0.85 \pm$ & $1.01 \pm$ & $7.2 \pm$ & $112 \pm$ & $5.5 \pm$ & $2.95 \pm$ & $3.6 \pm$ & $1.84 \pm$ \\
& 0.24 & 0.03 & 0.08 & 0.6 & 7.8 & 0.55 & 0.03 & 0.24 & 0.04 \\
Recovery & 88.2 & 90.4 & 98.1 & 93.5 & 81.2 & 90.2 & 80.8 & 80.0 & 93.9 \\
$(\%)$ & & & & & & & & & \\
\hline
\end{tabular}

$50 \% \mathrm{v} / \mathrm{v}$ nitric acid and the PET bottles were immersed in $5 \% \mathrm{v} / \mathrm{v}$ nitric acid for $24 \mathrm{~h}$ followed by rinsing with de-ionized water.

\subsection{Sample pretreatment and instrumental analysis}

The analytical procedure of OCPs was similar to the method in our previous work (Yang et al., 2004). Briefly, a suitable amount of well homogenized tissue was ground with activated sodium sulfate until a fine powder was obtained. The samples was extracted with $100 \mathrm{ml}$ of hexane-dichloromethane $(1: 1 \mathrm{v} / \mathrm{v})$ using sonication method for $40 \mathrm{~min}$, then stood overnight (about $10 \mathrm{~h}$ ) and was sonicated for $20 \mathrm{~min}$ again. Lipid content was determined gravimetrically using $20 \%$ of the extract. The other extract was subsequently concentrated on a rotary evaporator to about $1-2 \mathrm{ml}$ in a water bath at about $35^{\circ} \mathrm{C}$ and then purified on a glass column packed as follows: glass wool, $6 \mathrm{~g}$ of activated Florisil and $2 \mathrm{~g}$ of sodium sulfate. The packed column was pre-rinsed with $70 \mathrm{ml}$ of hexanedichloromethane $(1: 1 \mathrm{v} / \mathrm{v})$. The elution was subsequently carried out using $50 \mathrm{ml}$ of hexane containing $25 \%(\mathrm{v} / \mathrm{v})$ dichloromethane. The effluent was concentrated to $2-3 \mathrm{ml}$ and then was reduced finally to a volume of $0.5 \mathrm{ml}$ under a gentle stream of pure nitrogen for $\mathrm{GC}$ analysis.

The OCPs in the extracts were analyzed by an Agilent 6890A gas chromatography (GC) equipped with a ${ }^{63} \mathrm{Ni}$ electron capture detector (micro-ECD) (USA). The separation was achieved with a HP-5 fused silica capillary column $(30 \mathrm{~m}$ length $\times 0.25 \mathrm{~mm}$ i.d.) coated with $5 \%$ dimethylsiloxane (film thickness $0.25 \mu \mathrm{m}$ ). The whole system was controlled by a Hewlett Packard workstation. The oven

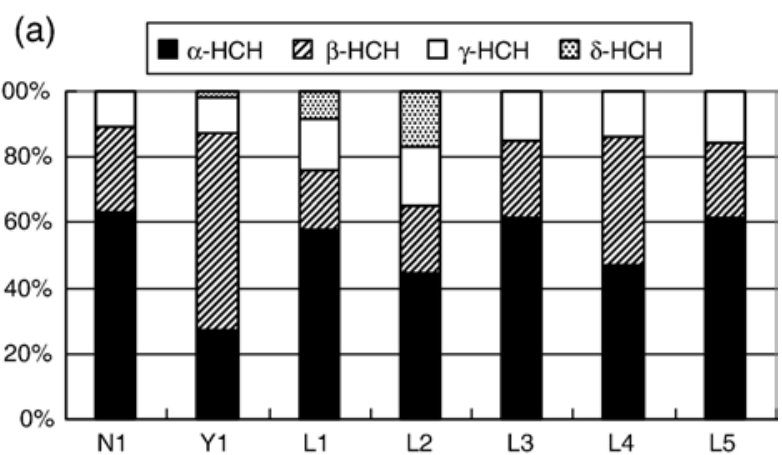

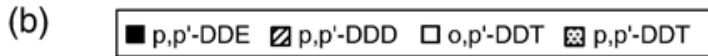

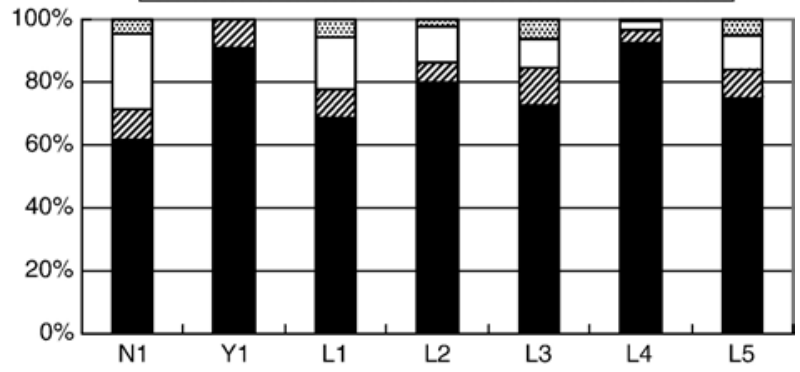

Fig. 2. Compositions of HCHs (a) and DDTs (b) in fish muscles from the Tibetan Plateau. (N1: Gymoncypris namensis; Y1: Gymoncypris waddellii; L1: Ptychobarbus dipogon; L2: Schizopygopsis stoliczkae; L3: Schizopygopsis younhusbandi; L4: Schizopygopsis microphalus; L5: Oxygymnocypris stewartii).

temperature program conditions were $80^{\circ} \mathrm{C}$ held for $2 \mathrm{~min}$, ramped at $10^{\circ} \mathrm{C} / \mathrm{min}$ to $140{ }^{\circ} \mathrm{C}$, and then at $4{ }^{\circ} \mathrm{C} / \mathrm{min}$ to $280^{\circ} \mathrm{C}$, and held for $10 \mathrm{~min}$. The temperatures of injector and detector were $250^{\circ} \mathrm{C}$ and $330^{\circ} \mathrm{C}$, respectively. About $1 \mu$ of extract was injected in the splitless mode. Highly pure nitrogen was used as the carrier gas with a flow rate of $1.0 \mathrm{ml} / \mathrm{min}$ and the make-up gas was controlled at $59 \mathrm{ml} / \mathrm{min}$. The main peaks were confirmed in selected samples by a Finnigan GC-MS-MS (PolarisQ, USA) using a 50-m DB-5 MS column with He carrier gas.

The selected organochlorine compounds were identified by retention time comparison by reference to the corresponding standard. Quantification was performed by the internal standard method using peak area of the compounds. The correlation coefficients $(r)$ of calibration curves of OCPs were all higher than 0.99. For each set of six samples, a procedural blank and a spiked sample with standards were run to check for the interference and cross-contamination. The IDLs of the instrument were in the range of $14 \mathrm{pg}$ for $\alpha-\mathrm{HCH}$ to $25 \mathrm{pg}$ for $\alpha-\mathrm{HCH}$ and the IQL were basically equal to the IDL. The method detection limits (MDLs) were described as 3:1 signal versus noise value $(\mathrm{S} / \mathrm{N})$. Table 2 illustrated the recoveries, MDLs, and the relative standard derivation (RSD) of the method. The MDLs ranged from $0.019 \mathrm{ng} / \mathrm{g}$ for $\alpha-\mathrm{HCH}$ to $0.055 \mathrm{ng} / \mathrm{g}$ for $p, p^{\prime}$-DDT. The spiked recoveries of OCPs using $1 \mathrm{ng}$ of composite standards were in the range of $88-103 \%$ and the RSD values with five times repeatedly determined was less than $13 \%$.

For heavy metals analysis, approximately $0.2 \mathrm{~g}$ (wet wt) of soft tissues was weighed in a PTFE digestion container. Each sample was added with $2 \mathrm{ml}$ of

Table 4

Concentrations of the selected OCPs in fish muscles from high mountain lakes and Lhasa River in the Tibetan Plateau (ng/g, wet wt)

\begin{tabular}{|c|c|c|c|c|c|c|c|c|c|c|c|c|}
\hline Location & Species & HCB & $\alpha-\mathrm{HCH}$ & $\beta-\mathrm{HCH}$ & $\gamma-\mathrm{HCH}$ & $\delta$ - $\mathrm{HCH}$ & $\sum \mathrm{HCH}$ & $p, p^{\prime}-\mathrm{DDE}$ & $p, p^{\prime}-\mathrm{DDD}$ & $o, p^{\prime}$-DDT & $p, p^{\prime}$-DDT & $\sum \mathrm{DDT}$ \\
\hline Nam Co Lake & Gymoncypris namensis & 3.2 & 1.63 & 0.66 & 0.28 & $<0.025$ & 2.6 & 14 & 2.2 & 5.7 & 1.0 & 23 \\
\hline Yamdro Lake & Gymoncypris waddellii & 0.85 & 0.43 & 0.96 & 0.17 & 0.031 & 1.6 & 2.5 & 0.26 & $<0.051$ & $<0.055$ & 2.8 \\
\hline \multirow[t]{5}{*}{ Lhasa River } & Ptychobarbus dipogon & 0.29 & 0.18 & 0.056 & 0.050 & 0.027 & 0.32 & 1.7 & 0.23 & 0.42 & 0.14 & 2.5 \\
\hline & Schizopygopsis stoliczkae & 0.58 & 0.068 & 0.031 & 0.027 & 0.026 & 0.13 & 0.63 & 0.047 & 0.090 & $<0.055$ & 0.78 \\
\hline & Schizopygopsis younhusbandi & 0.80 & 0.46 & 0.18 & 0.11 & $<0.025$ & 0.75 & 2.4 & 0.39 & 0.31 & 0.20 & 3.3 \\
\hline & Schizopygopsis microphalus & 0.31 & 0.14 & 0.11 & 0.040 & $<0.025$ & 0.29 & 3.8 & 0.17 & 0.11 & $<0.055$ & 4.1 \\
\hline & Oxygymnocypris stewartii & 0.91 & 0.45 & 0.17 & 0.11 & $<0.025$ & 0.74 & 5.5 & 0.65 & 0.82 & 0.38 & 7.4 \\
\hline
\end{tabular}


Table 5

Concentrations of heavy metals in fish muscles from high mountain lakes and Lhasa River in the Tibetan Plateau ( $\mu \mathrm{g} / \mathrm{g}$, wet wt)

\begin{tabular}{|c|c|c|c|c|c|c|c|c|c|c|}
\hline Location & Species & $\mathrm{Mn}$ & $\mathrm{Co}$ & $\mathrm{Ni}$ & $\mathrm{Cu}$ & $\mathrm{Zn}$ & As & $\mathrm{Se}$ & $\mathrm{Cd}$ & $\mathrm{Pb}$ \\
\hline Nam Co Lake & Gymoncypris namensis & 0.61 & 0.041 & 0.094 & 2.0 & 6.9 & 0.24 & 0.36 & 0.025 & 0.047 \\
\hline Yamdro Lake & Gymoncypris waddellii & 0.24 & 0.040 & 0.12 & 1.1 & 4.4 & 0.27 & 1.0 & 0.024 & 0.079 \\
\hline \multirow[t]{5}{*}{ Lhasa River } & Ptychobarbus dipogon & 0.19 & 0.041 & 0.11 & 0.33 & 3.3 & 0.067 & 0.23 & 0.024 & 0.024 \\
\hline & Schizopygopsis stoliczkae & 0.11 & 0.022 & 0.11 & 0.83 & 2.5 & 0.087 & 0.18 & 0.013 & 0.026 \\
\hline & Schizopygopsis younhusbandi & 0.46 & 0.048 & 0.14 & 0.88 & 5.3 & 0.12 & 0.27 & 0.027 & 0.065 \\
\hline & Schizopygopsis microphalus & 0.49 & 0.057 & 0.19 & 0.79 & 4.1 & 0.14 & 0.26 & 0.029 & 0.055 \\
\hline & Oxygymnocypris stewartii & 0.20 & 0.046 & 0.22 & 0.41 & 3.0 & 0.080 & 0.31 & 0.023 & 0.027 \\
\hline
\end{tabular}

concentrated nitric acid and left to predigest overnight at $40^{\circ} \mathrm{C}$. After cooling, $2 \mathrm{ml}$ of $30 \%$ hydrogen peroxide was added. Thereafter the container was covered and placed in a high-pressure stainless steel bomb then put in an oven. The oven temperature was increased to $160{ }^{\circ} \mathrm{C}$ and kept for $8 \mathrm{~h}$. After cooling, the solution was diluted with Milli-Q water and transferred into PET bottle to $25 \mathrm{~g}$.

$\mathrm{X}$ series inductively coupled plasma mass spectrometer (ICP-MS) (Thermo Electron Co. Ltd, USA) was used for the determination of metals. All analyses were repeated thrice by internal calibration method. The accuracy of the method was validated by the determination of mussel (GBW 08571) certified reference materials, and the results are reported in Table 3 . The found values of all elements were in good agreement with the certified values, with the recoveries ranging from $80.8 \%$ to $98.1 \%$, suggesting that the proposed method was feasible in the determination of heavy metals in biota samples.

\section{Results and discussion}

\subsection{Concentrations and patterns of OCPS}

Organochlorine concentrations in fish muscles are summarized in Table 4. DDT is the predominant pollutant. Concentrations of $\sum \mathrm{HCH}$, $\sum$ DDT and HCB were in the range of $0.13-2.6 \mathrm{ng} / \mathrm{g}$ (mean $0.91 \mathrm{ng} / \mathrm{g}$ ), $0.78-23 \mathrm{ng} / \mathrm{g}$ (mean $6.3 \mathrm{ng} / \mathrm{g}$ ), $0.31-3.2 \mathrm{ng} / \mathrm{g}$ (mean $1.0 \mathrm{ng} / \mathrm{g}$ ) based on wet weight, respectively. The highest OCP concentrations were found at higher altitude, e.g. the remotest sites ( $\mathrm{Nam} \mathrm{Co}$ ). This result might be explained by "cold condensation" theory, some semi-volatile organic compounds with high vapor pressure condense at cold latitude or altitude (Grimalt et al., 2001). The OCP concentrations in fish muscles in this study are comparable with those in fish from European high mountain lakes (Vives et al., 2004, 2005). Pearson's correlation of the concentrations of $\sum \mathrm{HCH}, \sum \mathrm{DDT}$ and $\mathrm{HCB}$ are significantly correlated with each other (HCB and $\sum \mathrm{HCH}: r=0.901, p<0.01$; $\mathrm{HCB}$ and $\sum \mathrm{DDT}$ : $r=0.939, p<0.01 ; \sum \mathrm{HCH}$ and $\sum \mathrm{DDT}: r=0.778, p<0.05$ ), which may suggest a similar origin.

Composition differences of $\mathrm{HCH}$ isomers or DDT congeners in the environment could indicate contamination source (Iwata et al., 1995). The relative percentage of HCHs is shown in Fig. 2a. The compositions

Table 6

Correlation matrixes of the concentrations of heavy metals in fish muscle

\begin{tabular}{lrrrllllll}
\hline & \multicolumn{1}{c}{$\mathrm{Mn}$} & $\mathrm{Co}$ & $\mathrm{Ni}$ & $\mathrm{Cu}$ & $\mathrm{Zn}$ & $\mathrm{As}$ & $\mathrm{Se}$ & $\mathrm{Cd}$ & $\mathrm{Pb}$ \\
\hline $\mathrm{Mn}$ & \multicolumn{1}{c}{1} & & & & & & & & \\
$\mathrm{Co}$ & 0.588 & 1 & & & & & & & \\
$\mathrm{Ni}$ & -0.050 & 0.594 & 1 & & & & & & \\
$\mathrm{Cu}$ & 0.690 & -0.091 & -0.513 & 1 & & & & & \\
$\mathrm{Zn}$ & $\mathbf{0 . 8 9 1}$ & 0.323 & -0.361 & $0.854^{*}$ & 1 & & & & \\
$\mathrm{As}$ & 0.476 & 0.079 & -0.363 & $0.779^{*}$ & 0.694 & 1 & & & \\
$\mathrm{Se}$ & -0.067 & 0.010 & -0.158 & 0.249 & 0.203 & $0.781^{*}$ & 1 & & \\
$\mathrm{Cd}$ & 0.696 & $\mathbf{0 . 9 4 6}$ & 0.318 & 0.105 & 0.542 & 0.281 & 0.149 & 1 & \\
$\mathrm{~Pb}$ & 0.458 & 0.383 & -0.085 & 0.399 & 0.546 & 0.751 & 0.711 & 0.521 & 1
\end{tabular}

Bold: Correlation is significant at the 0.01 level (two-tailed).

*Correlation is significant at the 0.05 level (two-tailed). of HCHs changed with different sampling sites and different species. Technical $\mathrm{HCH}$ usually contains $55-80 \%$ of $\alpha-\mathrm{HCH}, 5-14 \%$ of $\beta-\mathrm{HCH}$, $8-15 \%$ of $\gamma-\mathrm{HCH}$ and $2-16 \%$ of $\delta-\mathrm{HCH}$, respectively (Willett et al., 1998). The physicochemical properties of these isomers are different. $\beta-\mathrm{HCH}$ has the lowest water solubility and vapor pressure, which is the most stable and relatively resistant to microbial degradation. Also it should be noted that $\alpha$ - and $\gamma$-isomer can be photolytically converted to $\beta-\mathrm{HCH}$ in the environment (Walker, 1999). In our samples, the average concentrations of $\alpha-, \beta-, \gamma$-, and $\delta$-isomers were observed to contribute $27-64 \%$ (mean $52 \%$ ), $18-40 \%$ (mean 30\%), 11-18\% (mean 14\%) and $0-17 \%$ (mean $4 \%$ ), respectively. A predominance of the $\alpha$-isomer in environmental samples reflects pollution of $\mathrm{HCH}$ technical mixtures. India and China are probably the major contributors of OCP pollution in Tibetan Plateau because of their immediate vicinity and because of their extensive application of technical $\mathrm{HCH}$ in the past. The transport and fate of pollutants to the Tibetan Plateau are expected to be influenced by two distinct monsoon systems that operate in the region: the Southwest or summer monsoon and the Northeast or winter monsoon (Pant and Rupa Kumar, 1997). The contribution of $\beta-\mathrm{HCH}$ was elevated about 3 times compared with the original composition, which might be attributed to different properties of the isomers. Migration and transformation can account for the elevated $\beta$-isomer component.

Technical DDT generally contains 75\% $p, p^{\prime}$-DDT, $15 \% o, p^{\prime}$-DDT, $5 \%$ $p, p^{\prime}$-DDE, and $<5 \%$ for others. DDT can be biodegraded to more persistent DDE under aerobic conditions and to DDD under anaerobic conditions. The relative percentage of DDTs is shown in Fig. $2 b$. The conger of $p, p^{\prime}$ DDE was found to be a major component ranging from $62 \%$ to $93 \%$ with a mean of $77 \%$. Comparing the ratio of $p, p^{\prime}$-DDT to $p, p^{\prime}$-DDE in the fish muscle from our study (mean 0.05 ) with the fish muscle from other regions such as the European high mountain regions (mean 0.39) (Vives et al.,

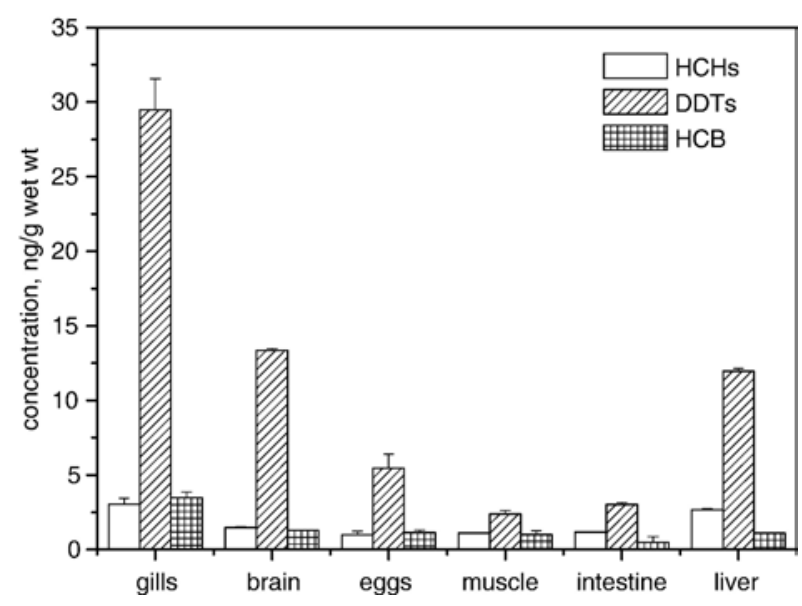

Fig. 3. Body distributions of OCPs in Gymoncypris waddellii from Yamdro Lake. 


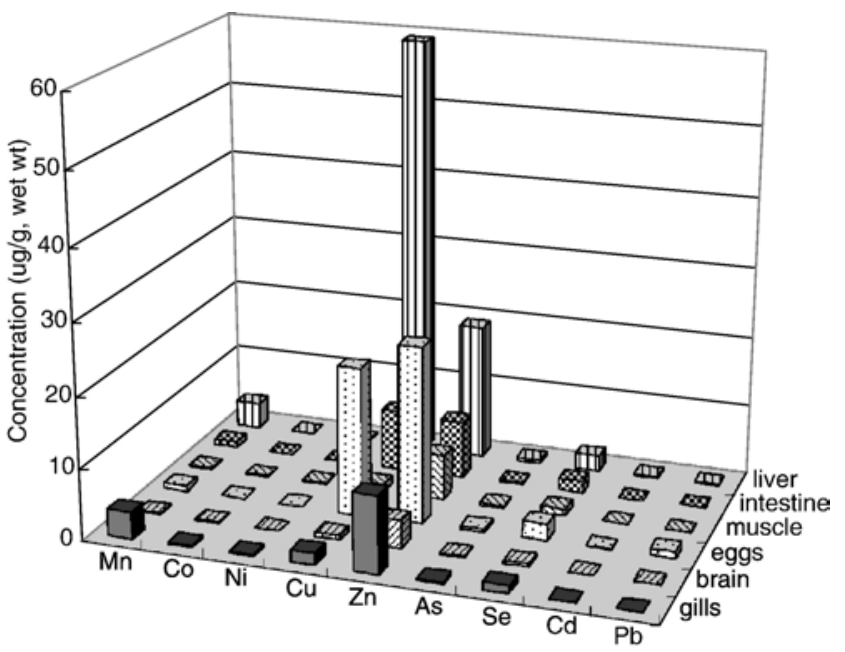

Fig. 4. Body distributions of heavy metals in Gymoncypris waddellii from Yamdro Lake.

2004) comprehended a low ratio in the Tibetan Plateau. However, the ratio of $o, p^{\prime}$-DDT to $p, p^{\prime}$-DDT, ranging from 0.9 to 5.7 (mean 3.3), was surprisingly higher compared with the original composition of technical DDT $\left(o, p^{\prime}\right.$-DDT $/ p, p^{\prime}$-DDT $\left.=0.2\right)$. According to a recent study by Qiu et al. (2005), Dicofol type DDT pollution can elevate the ratio of $o, p^{\prime}$-DDT to $p$, $p^{\prime}$-DDT and of $p, p^{\prime}$-DDE to $p, p^{\prime}$-DDT. Therefore judging the DDT source by the ratios between congeners should be cautious because of the current production and usage of Dicofol in Asian countries such as China and India (Plassche et al., 2000).

\subsection{Heavy metal concentrations}

Several studies confirmed that heavy metals can reach the remote alpine regions by long-range transport through the atmosphere (Zechmeister, 1995; Schilling and Lehman, 2002; Yang et al., 2002). Anthropogenic heavy metals can affect the biogeochemical processes and the ecosystem's health for a long time.

The contents of the selected heavy metals in fish muscles are summarized in Table 5. It is apparent that all samples contaminated with different levels of heavy metals. The $\mathrm{Cu}$ and $\mathrm{Zn}$ levels were extraordinarily high with the maximum concentrations of 2.0 and $6.9 \mu \mathrm{g} / \mathrm{g}$, respectively, in Gymoncypris namensis from Nam Co Lake. Mn, Ni and $\mathrm{Se}$ that were less than $\mathrm{Cu}$ and $\mathrm{Zn}$, still higher than other metals such As $\mathrm{Cd}, \mathrm{Pb}, \mathrm{Co}$ among which $\mathrm{As}, \mathrm{Cd}, \mathrm{Pb}$ should be taken into particular account due to their harmful effects. For instance, $\mathrm{Pb}$ and its salts were capable of damaging the nerve system, hematosis and kidney in the body of fish or human being (Chuang et al., 2004). As a whole, all metal concentrations were below the maximum permissible levels (MPLs) according to the codes of WHO (1982).

Results of correlation analyses (bivariate correlations with Pearson's correlation coefficients) among these heavy metal concentrations are listed in Table $6(P<0.05$ or $P<0.01)$. There were some correlations among concentrations of metals found in the samples (e.g., $\mathrm{Mn}-\mathrm{Zn}, \mathrm{Co}-$ $\mathrm{Cd}, \mathrm{Zn}-\mathrm{Cu}, \mathrm{As}-\mathrm{Cu}, \mathrm{As}-\mathrm{Se}$ ). This result can provide some information on the metal origin or a certain bioaccumulation mechanism by an organism.

\subsection{Body distribution of OCPs and heavy metals}

In order to investigate the distribution status of the pollutants in the organism's tissues, Gymoncypris waddellii from the Yamdro Lake were dissected into six parts, i.e., muscle, gill, brain, intestine, liver and egg, and concentrations of OCPs and heavy metals of each part were measured. The fish studied were about 10 years old according to their body weight and length (Chen et al., 2002) and therefore monitored data reflected a long-term environmental exposure. The results demonstrate that different tissues of fish have quite different concentrations of OCPs (Fig. 3). Prominently, the sum of DDTs was found much higher than that of HCB and sum of HCHs in the tissues or organs. However, the three kinds of OCPs show the similar concentration distribution in the tissues or organs. Gill, liver and brain seem to accumulate relatively higher concentrations of OCPs than other tissues. Particularly, much higher levels of OCPs were found in the gills, which can be explained by its larger surface areas per gram of tissue since gill can continuously transfer the organic pollutants from both water and suspended particles onto its surface.

Compared with the OCPs, the distribution of heavy metals was different (Fig. 4). In general, concentrations were high in liver, eggs and gill, and low in brain and muscle. The highest $\mathrm{Cu}$ concentration (59 $\mu \mathrm{g} / \mathrm{g}$ wet wt) in liver was about sixty-fold as high as those in the muscle of the fish. Interestingly, some specific distribution was also observed for the selected metals. Greater concentrations of $\mathrm{Mn}, \mathrm{Co}, \mathrm{Ni}$ and $\mathrm{Cd}$ were found in gill. However, levels of $\mathrm{Zn}, \mathrm{As}, \mathrm{Se}$ and $\mathrm{Pb}$ in the eggs were relatively high, which means that the elimination of these heavy metals through egg laying is significant.

\section{Conclusion}

Accumulation of the OCPs and heavy metals in fish from alpine aquatic ecosystems in Tibetan Plateau was studied. Results from this study validate that the Tibetan Plateau acts as a regional contaminant convergence zone. Because of the limited samples, this research do not allow for a complete understanding of pollution status and the factors regulating the transport of persistent pollutants such as OCPs and heavy metals in a remote environment, hence a comprehensive study is still needed.

\section{Acknowledgements}

This research was supported by the National Basic Research Program of China (2003CB415001). We express our gratitude to Prof. Shichang Kang, Zonghu Huang and other members in Nam Co Station for their kind help in sample collection. We also greatly appreciate suggestions from anonymous referees for the improvement of our paper.

\section{References}

Atlas E, Giam CS. Global transport of organic pollutants: ambient concentrations in the remote marine atmosphere. Science 1981;211:163-5.

Blais JM, Schindler DW, Muir DCG, Kimpes LE, Donald DB, Rosenberg M. Accumulation of persistent organochlorine compounds in mountains of western Canada. Nature 1998;395:585-8.

Carrera G, Fernández P, Vilanova RM, Grimalt JO. Persistent organic pollutants in snow from European high mountain areas. Atmos Environ 2001;35:245-54.

Chen YF, He DK, Chen YY. Age discrimination of Selincuo Schizothoracini (Gymnocypris selincuoensis) in Selincuo Lake, Tibetan Plateau. Acta Zool Sin 2002;48:527-33.

Chuang HY, Tsai SY, Chao KY, Lian CY, Yang CY, Ho CK. The influence of milk intake on the lead toxicity to the sensory nervous system in lead workers. Neurotoxicol 2004;25:941-9.

Daly GL, Wania F. Organic contaminants in mountains. Environ Sci Technol 2005;39:385-98. 
Davidson DA, Wilkinson AC, Blais JM, Kimpe LE, Mcdonald KM, Schindler DW. Orographic cold-trapping of persistent organic pollutants by vegetation in mountains of western Canada. Environ Sci Technol 2003;37:209-315.

Drooge BLV, Grimalt JO. Atmospheric semivolatile organochlorine compounds in European high-mountain areas (central Pyrenees and high Tatras). Environ Sci Technol 2004;38:3625-32.

Franz TP, Eisenreich SJ. Snow scavenging of polychlorinated biphenyls and polycyclic aromatic hydrocarbons in Minnesota. Environ Sci Technol 1998;32:1771-8.

Grimalt JO, Fernández P, Berdie L, Vilanova RM, Catalan J, Psenner R, et al. Selective trapping of organochlorine compounds in mountain lakes of temperate areas. Environ Sci Technol 2001;35:2690-7.

Kidd KA, Schindler DW, Muir DCG, Lockhart WL, Hesslein H. High concentrations of toxaphene in fishes from a subarctic lake. Science 1995;269:240-2.

Iwata H, Tanabe S, Ueda K, Tatsukawa R. Persistent organochlorine residues in air, water, sediments, and soils from the lake Baikal region, Russia. Environ Sci Technol 1995;29:792-801.

Li YF, Macdonald RW. Sources and pathways of selected organochlorine pesticides to the Arctic and the effect of pathway divergence on $\mathrm{HCH}$ trends in biota: a review. Sci Total Environ 2005;342:87-106.

Li YF, Cai DJ, Singh A. Technical hexachlorocyclohexane use trends in China and their impact on the environment. Arch Environ Contam Toxicol 1998;35:688-97.

Pant GB, Rupa Kumar K. Climates of South Asia. Chichester: John Wiley and Sons; 1997.

Plassche EJ, Schwegler AMGR, Rasenberg M, Schouten G. DDT in Dicofol. http://www.unece.org2000.

Qiu XH, Zhu T, Yao B, Hu JX, Shu SW. Contribution of Dicofol to the current DDT pollution in China. Environ Sci Technol 2005;39:4385-90.

Schilling JS, Lehman ME. Bioindication of atmospheric heavy metal deposition in the Southeastern US using the moss Thuidium delicatulum. Atmos Environ 2002;36:1611-8.
Shen L, Wania F, Lei YD, Teixeira C, Muir DCG, Bidleman TF. Atmospheric distribution and long-range transport behavior of organochlorine pesticides in North America. Environ Sci Technol 2005;39:409-20.

UNEP (United Nations Environment Programme Chemicals). Chemicals Central and North East Asia Regional Report. Regionally based assessment of persistent toxic substances. Chatelaine, Switzerland: UNEP Chemicals; 2002.

Vives I, Grimalt JO, Catalan J, Rosseland BO, Battarbee RW. Influence of attitude and age in the accumulation of organochlorine compounds in fish from high mountain lakes. Environ Sci Technol 2004;38:690-8.

Vives I, Grimalt JO, Ventura M, Catalan J, Rosseland BO. Age dependence of the accumulation of organochlorine pollutants in brown trout (Salmo trutta) from a remote high mountain lake (RedÓ, Pyrenees). Environ Pollut 2005; 133:343-50

Walker K. Factors influencing the distribution of lindane and other hexachlorocyclohexanes in the environment. Environ Sci Technol 1999;33:4373-8.

WHO. Toxicological evaluation of certain food additives and contaminants. Joint FAO/WHO expert committee on food additives. WHO Food Additives SeriesGeneva: World Health Organization; 1982. p. 28-35.

Willett KL, Ulrich EM, Hites RA. Differential toxicity and environmental fates of hexachlorocyclohexane isomers. Environ Sci Technol 1998;32:2197-207.

Wu YF, Wu CZ. The fishes of the Qinghai-Xizang Plateau. Chengdu, China: Sichuan Publishing House of Science \& Technology; 1992.

Yang HD, Rose NL, Battarbee RW. Distribution of some trace metals in Lochnagar, a Scottish mountain lake ecosystem and its catchment. Sci Total Environ 2002;285:197-208.

Yang RQ, Yao ZW, Jiang GB, Zhou QF, Liu JY. HCH and DDT residues in molluscs from Chinese Bohai coastal sites. Mar Pollut Bull 2004;48:795-9.

Zechmeister HG. Correlation between altitude and heavy metal deposition in the ALPs. Environ Pollut 1995;89:73-80. 